\title{
CURRENT STATUS AND INTEGRATED POLLUTION CONTROL OF BLACK AND ODOROUS WATER BODIES IN DONGXINKAI RIVER BASIN OF CHINA
}

\author{
ZHAO, S. Y. ${ }^{1}-$ WANG, D. D. ${ }^{1}-$ WANG, Y. L. ${ }^{2}-$ CHEN, L. ${ }^{1 *}$ \\ ${ }^{1}$ College of Municipal and Environmental Engineering, Jilin Jianzhu University \\ Changchun 130000, China \\ ${ }^{2}$ Urban and Rural Planning and Design Institute of Jilin Province \\ Changchun 130000, China \\ *Corresponding author \\ e-mail: coffeezsy@163.com \\ (Received $7^{\text {th }}$ Jun 2019; accepted $10^{\text {th }}$ Oct 2019)
}

\begin{abstract}
This paper monitors and analyzes the surface water and sediments in the Dongxinkai (DXK) River basin. The analysis shows that the water bodies mainly suffer from aerobic pollution, with chemical oxygen demand (COD) and ammonia nitrogen $\left(\mathrm{NH}_{3}-\mathrm{N}\right)$ being the primary causes of pollution. Considering the main causes of the pollution, the author put forward an integrated pollution control plan for the basin focusing on pollutant interception, source control, and ecological construction. After the treatment, the dissolved oxygen (DO) values at all sampling points were greater than $2 \mathrm{mg} / \mathrm{L}$, the $\mathrm{NH}_{3}-\mathrm{N}$ values were all smaller than $8 \mathrm{mg} / \mathrm{L}$ and the water transparency values were all above $25 \mathrm{~cm}$, indicating that the river is no longer black or odorous. The implementation of the entire plan costs RMB $26.2 \times 10^{8}$ yuan. The research findings shed important new lights on pollution control in other rivers across China. Keywords: black and odorous waterbody, chemical oxygen demand (COD), ammonia nitrogen $\left(\mathrm{NH}_{3}-\mathrm{N}\right)$, wetland, sponge city
\end{abstract}

\section{Introduction}

As urbanization has been picking up speed in China, a lot of sewage have been discharged into rivers without any treatment. As a result, water quality indices like chemical oxygen demand (COD), ammonia nitrogen $\left(\mathrm{NH}_{3}-\mathrm{N}\right)$ and total phosphorus (TP) have greatly surpassed limits in many rivers, making the water bodies black and odorous (Wang et al., 2014, 2016a; Corsino et al., 2016). In 2015, the State Council, China's cabinet, unveiled its Action Plan for Water Pollution Prevention and Control, setting out the goal to control the proportion of black and odorous water bodies in urban built-up regions at prefecture-level and push it below 10\% by 2020 (Chi et al., 2019; Li et al., 2018).

In light of the above, this paper attempts to prepare an integrated plan to solve the water pollution in the basin of Dongxinkai (DXK) River, northeastern China's Jilin Province, aiming to control the water quality indices within the limits. The prepared plan would promote the construction of sponge cities and provide reference to river pollution control across China.

With a basin of $98.12 \mathrm{~km}^{2}$, the DXK River is a $16.5-\mathrm{km}$-long primary tributary of Yitong River, which crisscrosses Jilin Province. The mean slope of the river is about 1.5\%o. The main tributaries include Xibaizi (XBZ) Ditch, Dabaizi (DBZ) Ditch, Baizi (BZ) Ditch, Weizi (WZ) Ditch, Jinqian (JQ) Ditch, etc. Currently, the water bodies are of poor quality in the river basin. The COD and nutrient salts (nitrogen and phosphorus) 
far exceed their respective limits. As a typical black and odorous water bodies, the river and its tributaries cannot even reach Class V specified in China's environmental quality standard for surface water, which seriously affects the life quality of nearby residents. This calls for immediate pollution control and regulation.

\section{Materials and methods}

\section{Sampling and analysis method}

During 11:00-15:00 on March 22- 25, 2016, the project team collected water samples from $50 \mathrm{~cm}$ of obvious flow on both Banks and river center in each monitoring section at the same time. After fully mixing, $500 \mathrm{ml}$ of mixed water samples were taken, sealed with polyethylene bottles, and brought back to the laboratory for physical and chemical determination within $24 \mathrm{~h}$. Each indicator of each water sample was measured three times and averaged. The surface water and sediment samples were collected from 29 points (Fig. 1) in the DXK River and its main tributaries. During the collection, a YSI (Yellow Springs Instrument Co) water quality meter and other portable water quality analyzers were adopted to measure the following indices of the surface water samples: temperature, $\mathrm{pH}$, oxidation reduction potential (ORP), conductivity and dissolved oxygen (DO) (Moungar et al., 2018; Uddin et al., 2017; Zhao et al., 2016, 2019). Meanwhile, the surface sediments were collected with a gravity column sampler (Behaddya and Hadjel, 2014; Bhuiyan et al., 2010; Wang et al., 2016).

The sediments were analyzed to determine their water content, organic content, particle size and heavy metal content. Specifically, the distribution of particle size was determined by a laser particle size analyzer, while the heavy metal content was measured by inductively coupled plasma optical emission spectrometry (ICP-OES). Before the ICP-OES, the sediment samples were freeze-dried by a freeze dryer, and then digested by microwave (Zhou et al., 2011).

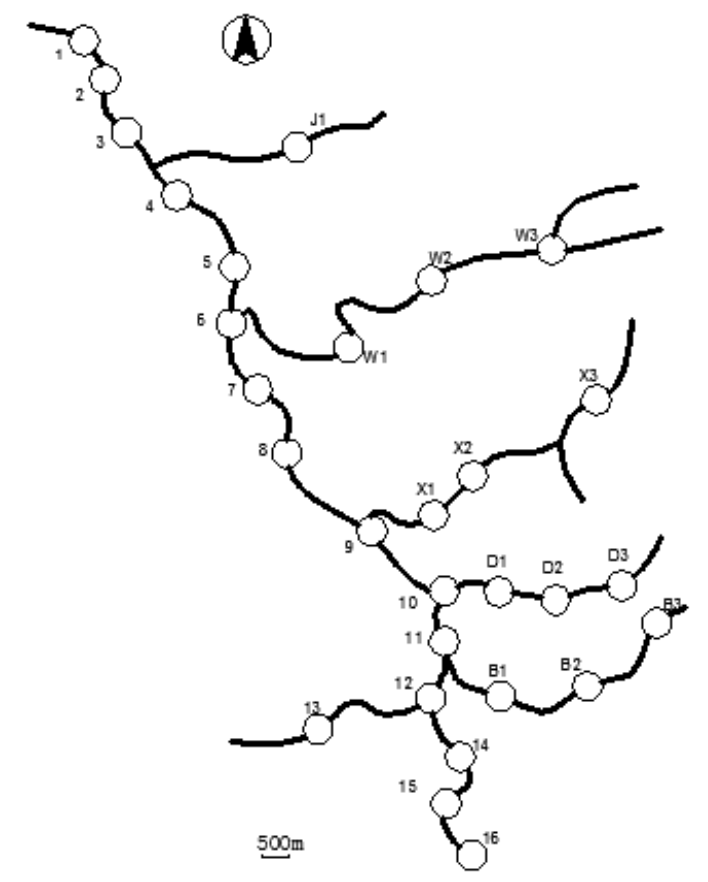

Figure 1. Distribution of sampling points 


\section{Water quality analysis}

The results of water quality and sediment analysis are listed in Table 1. In general, the surface water COD in the river basin fell in 13 222 mg/L, averaging at $106.9 \mathrm{mg} / \mathrm{L}$. The WZ Ditch and DBZ Ditch had relatively high mean CODs, respectively, $166 \mathrm{mg} / \mathrm{L}$ and $148 \mathrm{mg} / \mathrm{L}$. The values were 4 and 5 times that for Class $\mathrm{V}$ in China's environmental quality standard for surface water. In the main stream, the COD at about $82 \%$ of sampling points was greater than the Class V level.

Table 1. Results of surface water quality and sediment analysis

\begin{tabular}{|c|c|c|c|c|c|c|c|c|c|c|c|}
\hline & \multicolumn{6}{|c|}{ Results of surface water quality analysis } & \multicolumn{5}{|c|}{ Results of sediment analysis } \\
\hline $\begin{array}{c}\text { Sampling } \\
\text { point }\end{array}$ & $\begin{array}{l}\text { COD } \\
\mathrm{mg} / \mathrm{L}\end{array}$ & \begin{tabular}{|c|}
$\mathrm{NO}_{3}-\mathrm{N}$ \\
$\mathrm{mg} / \mathrm{L}$
\end{tabular} & $\begin{array}{c}\mathrm{NH}_{3}-\mathrm{N} \\
\mathrm{mg} / \mathrm{L}\end{array}$ & $\begin{array}{c}\mathrm{TN} \\
\mathrm{mg} / \mathrm{L}\end{array}$ & $\begin{array}{c}\text { TP } \\
\mathrm{mg} / \mathrm{L}\end{array}$ & $\begin{array}{c}\text { SRP } \\
\mathrm{mg} / \mathrm{L}\end{array}$ & $\begin{array}{c}\mathrm{TN} \\
\mathrm{mg} / \mathrm{kg}\end{array}$ & $\begin{array}{c}\mathrm{TP} \\
\mathrm{mg} / \mathrm{kg}\end{array}$ & $\begin{array}{l}\text { TC } \\
\%\end{array}$ & $\begin{array}{l}\text { TS } \\
\%\end{array}$ & $\begin{array}{c}\text { LOI } \\
\%\end{array}$ \\
\hline 1 & 100 & 0.05 & 14.2 & 28.13 & 1.87 & 1.98 & 3218.4 & 1456.8 & 5.2 & 0.21 & 0.083 \\
\hline 2 & 98 & 0.28 & 14.1 & 28.10 & 5.16 & 5.46 & 898.5 & 500.3 & 0.2 & 0.03 & 0.064 \\
\hline 3 & 122 & 0.97 & 15.1 & 28.11 & 2.13 & 2.13 & 1998.6 & 478.6 & 1.8 & 0.07 & 0.072 \\
\hline 4 & 120 & 0.55 & 16.2 & 39.24 & 1.71 & 1.88 & 3048.5 & 1639.6 & 3.7 & 0.22 & 0.058 \\
\hline 5 & 126 & 0.68 & 17.2 & 23.52 & 3.69 & 3.78 & 3128.7 & 1586.9 & 3.6 & 0.18 & 0.046 \\
\hline 6 & 118 & 0.57 & 15.2 & 30.26 & 1.54 & 1.63 & 2082.3 & 456.9 & 2.9 & 0.16 & 0.135 \\
\hline 7 & 130 & 0.60 & 16.3 & 21.68 & 1.62 & 1.67 & 2278.6 & 698.3 & 2.8 & 0.07 & 0.033 \\
\hline 8 & 126 & 0.62 & 15.4 & 20.96 & 1.60 & 1.65 & 789.9 & 121.6 & 3.9 & 0.31 & 0.065 \\
\hline 9 & 25 & 1.08 & 5.9 & 4.61 & 0.17 & 0.26 & 2001.9 & 689.7 & 3.5 & 0.25 & 0.054 \\
\hline 10 & 96 & 0.28 & 11.8 & 18.15 & 3.06 & 3.52 & 1978.6 & 498.6 & 3.8 & 0.26 & 0.057 \\
\hline 11 & 119 & 0.34 & 20.4 & 28.74 & 4.79 & 5.03 & 438.6 & 396.5 & 0.9 & 0.04 & 0.051 \\
\hline 12 & 32 & 3.45 & 1.04 & 13.11 & 0.43 & 0.63 & 1847.7 & 452.3 & 2.1 & 0.06 & 0.047 \\
\hline 13 & 220 & 4.57 & 51.3 & 77.61 & 6.05 & 5.92 & 5875.1 & 426.9 & 2.3 & 0.05 & 0.049 \\
\hline 14 & 220 & 4.01 & 46.7 & 60.41 & 5.82 & 5.63 & 431.6 & 415.6 & 0.3 & 0.03 & 0.028 \\
\hline 15 & 30 & 4.98 & 1.97 & 15.84 & 0.36 & 0.42 & 3568.7 & 894.6 & 5.1 & 0.14 & 0.084 \\
\hline 16 & 121 & 0.04 & 6.87 & 17.26 & 1.12 & 1.44 & 1894.5 & 487.7 & 2.9 & 0.08 & 0.048 \\
\hline $\mathrm{J} 1$ & 78 & 0.28 & 9.87 & 13.27 & 0.71 & 0.65 & 3248.6 & 600.1 & 3.1 & 0.16 & 0.063 \\
\hline W1 & 220 & 2.88 & 81.2 & 107.7 & 10.12 & 8.82 & 214.9 & 587.6 & 1.6 & 0.02 & 0.028 \\
\hline W2 & 222 & 2.65 & 70.6 & 44.91 & 6.73 & 6.12 & 1846.5 & 189.6 & 1.5 & 0.03 & 0.025 \\
\hline W3 & 196 & 0.78 & 0.91 & 18.79 & 2.61 & 2.63 & 5876.4 & 689.1 & 6.6 & 0.12 & 0.011 \\
\hline $\mathrm{X} 1$ & 26 & 0.58 & 3.12 & 11.54 & 0.52 & 0.29 & 687.6 & 220.3 & 4.3 & 0.06 & 0.016 \\
\hline $\mathrm{X} 2$ & 20 & 0.50 & 1.25 & 12.83 & 0.13 & 0.13 & 690.5 & 497.6 & 2.4 & 0.09 & 0.009 \\
\hline $\mathrm{X} 3$ & 71 & 2.98 & 5.37 & 13.69 & 0.68 & 0.33 & 246.8 & 498.9 & 1.6 & 0.11 & 0.008 \\
\hline D1 & 39 & 0.58 & 0.08 & 12.16 & 0.50 & 0.24 & 278.6 & 396.5 & 1.4 & 0.07 & 0.010 \\
\hline D2 & 197 & 5.83 & 10.16 & 70.61 & 11.24 & 10.21 & 428.7 & 788.6 & 3.9 & 0.05 & 0.011 \\
\hline D3 & 188 & 0.57 & 24.5 & 36.83 & 0.48 & 0.21 & 528.6 & 758.3 & 4.1 & 0.06 & 0.013 \\
\hline B1 & 39 & 2.87 & 2.01 & 14.21 & 0.51 & 0.23 & 2000.2 & 425.3 & 5.1 & 0.31 & 0.014 \\
\hline B2 & 40 & 2.45 & 6.37 & 16.53 & 0.54 & 0.35 & 398.3 & 345.6 & 1.7 & 0.05 & 0.135 \\
\hline B3 & 13 & 3.31 & 0.09 & 15.64 & 0.41 & 0.01 & 401.2 & 754.6 & 3.0 & 0.21 & 0.012 \\
\hline
\end{tabular}

* $\mathrm{NO}_{3}-\mathrm{N}$ : nitrate nitrogen. TC: total carbon. SRP: soluble reactive phosphorus. TS: total sulfur. LOI: loss on ignition. COD: chemical oxygen demand. TN: total nitrogen. TP: total phosphorus. $\mathrm{NH}_{3}-\mathrm{N}$ : ammonia nitrogen 
The $\mathrm{NH}_{3}-\mathrm{N}$ in the water bodies ranged between $0.04 \mathrm{mg} / \mathrm{L}$ and $5.83 \mathrm{mg} / \mathrm{L}$. In the main stream and each tributary, the $\mathrm{NH}_{3}-\mathrm{N}$ gradually decreased streamwise. The mean $\mathrm{NH}_{3}-\mathrm{N}$ was the highest in the BZ Ditch, while that of the WZ Ditch and the DBZ Ditch were $36 \mathrm{mg} / \mathrm{L}$ and $13.1 \mathrm{mg} / \mathrm{L}$ respectively. In the main stream, the $\mathrm{NH}_{3}-\mathrm{N}$ exhibited an obvious spatial difference. In the downstream, the $\mathrm{NH}_{3}-\mathrm{N}$ obeyed a relatively uniform distribution and all exceeded the Class $\mathrm{V}$ level. This is attributable to the industrial wastewater and domestic sewage discharged from cities, towns and villages.

The total nitrogen (TN) fluctuated between $4.61 \mathrm{mg} / \mathrm{L}$ and $107.7 \mathrm{mg} / \mathrm{L}$ across the river basin, and always stayed above the Class $\mathrm{V}$ level. The peak TN was observed at the sampling point $\mathrm{W} 1$, about 54 times the Class V level. This means all water bodies in the basin have been seriously polluted by nitrogen.

The mean TP in the basin stood at $2.4 \mathrm{mg} / \mathrm{L}$, more than 7 times the Class V level $(0.4 \mathrm{mg} / \mathrm{L})$.

The soluble reactive phosphorus (SRP) of the basin averaged at $2.26 \mathrm{mg} / \mathrm{L}$, indicating that an average of $84 \%$ phosphorus in the water bodies mainly exist in the dissolved state. The SRP proportion of the main stream even surpassed $90 \%$.

\section{Sediment analysis}

The analysis results in Table 1 show that the TP of surface sediments in the basin averaged at $613.03 \mathrm{mg} / \mathrm{kg}$, far above the internationally accepted TP threshold $(500 \mathrm{mg} / \mathrm{kg})$ for sediments. The $\mathrm{TN}$ of surface sediments in the basin averaged at $1,951.3 \mathrm{mg} / \mathrm{kg}$. This level greatly surpassed the internationally accepted TN threshold $(1,000 \mathrm{mg} / \mathrm{kg})$ for sediments, posing the risk of pollutant release.

The sediment samples differed greatly in total carbon (TC), which ranged between $0.27 \%$ and $6.6 \%$. The peak TC belonged to the sampling point W3. The distribution of TC changed significantly from place to place in the tributaries.

The total sulfur (TS) of sediment samples, an indicator of pollutant content, averaged at $0.113 \%$, and peaked at sampling points 8 and B1. The spatial distribution of TS was relatively stable.

The loss on ignition (LOI) characterizes how much organic matter exists in the sediments, and how much gaseous products come from the thermal decomposition of sediments. The analysis results demonstrate an obvious difference in organic content between sediment samples. The highest organic content was discovered at sampling points 6 and B2. Therefore, TC and LOI must have similar pollution sources.

The author monitored 29 sampling points with 4 indicators including TN, TP, COD and $\mathrm{NH}_{3}-\mathrm{N}$ for a total of 4 times in March 2016, and extracted 3 samples from each sampling point for a total of $1392(29 \times 4 \times 12)$ monitoring samples for laboratory analysis. The specific statistical description of the results is shown in Table 2. According to the statistical data, the flowing water of this river is seriously polluted. $\mathrm{TN}, \mathrm{NH}_{3}-\mathrm{N}$ and $\mathrm{TP}$ all seriously exceed the category $\mathrm{V}$ of surface water environmental quality standards. Normal test was carried out on the average data set of sampling points, and the results showed that all monitoring indexes except TN followed normal distribution with $95 \%$ or higher reliability.

\section{Diagnosis of water environment problems}

The water bodies in the river basin mainly suffers from aerobic pollution, with COD and $\mathrm{NH}_{3}-\mathrm{N}$ being the primary pollutants. According to the analysis on surface water 
quality indices, the surface water is severely polluted by nutrient salts. On average, the surface water samples exceeded the standard level by 7.3 times, 13.6 times, 5.8 times and 2.6 times in terms of $\mathrm{NH}_{3}-\mathrm{N}, \mathrm{TN}, \mathrm{TP}$ and COD. Considering the current states of pollution and sewage pipe network, the blackness and odor of the water bodies can be attributed to the following reasons:

(1) Our survey shows that agricultural land $\left(63.02 \mathrm{~km}^{2}\right)$ takes up $64.2 \%$ of the river basin $\left(98.12 \mathrm{~km}^{2}\right)$; For the pollution load of the basin, $70 \%$ comes from agricultural non-point source pollution and 5\% from scattered discharge of rural sewage. Thus, the rural area is the main contributor to non-point source pollution of the basin. The nonpoint source pollution load in the river basin is specified in Table 3.

(2) There is no sewage treatment plant in the river basin. Neither has any sewage treatment plant been planned for this region. The sewage is mainly collected by the pipe network, and transported to the Beijiao Sewage Treatment Plant in the downstream. As a result, the water flow in the middle and lower reaches of the DXK River is not stable. The river often dries up in the dry season.

(3) The runoff is seriously polluted in rainy days. In the basin, the rainwater and sewage are still discharged in the same pipe network. During rainstorms, the sewage often flows over and carry garbage into the river.

(4) The rivers have weak self-purification ability due to ecological degradation. The river basin does not have enough ecological space (Podani, 1994; Xu, 2005). Many river channels are illegally occupied by buildings and lots of beaches are turned into farmland, leaving a narrow watercourse for flood discharge (Lazaro, 1979). These behaviors severely undermine the regional flood control and discharge, water regulation and storage, river self-purification and river landscape. This is the main threat to the ecological space of the river basin.

Table 2. Statistical description of water quality variables and the environmental guideline of national quality standards for surface waters

\begin{tabular}{c|c|c|c|c}
\hline Parameter & $\begin{array}{c}\mathbf{T N} \\
\mathbf{m g} / \mathbf{L}\end{array}$ & $\begin{array}{c}\mathbf{N} \mathbf{N H}_{\mathbf{3}}-\mathbf{N} \\
\mathbf{m g} / \mathbf{L}\end{array}$ & $\begin{array}{c}\mathbf{T P} \\
\mathbf{m g} / \mathbf{L}\end{array}$ & $\begin{array}{c}\mathbf{C O D} \\
\mathbf{m g} / \mathbf{L}\end{array}$ \\
\hline Mean value & 29.154 & 17.442 & 2.658 & 7.352 \\
Standard deviation & 2.48 & 2.16 & 0.34 & 0.98 \\
Standard error & 0.13 & 0.11 & 0.02 & 0.09 \\
Least value & 4.61 & 0.09 & 0.13 & 13 \\
Maximum value & 107.7 & 81.2 & 11.24 & 222 \\
\hline I* & 0.2 & 0.15 & 0.02 & 2 \\
II & 0.5 & 0.5 & 0.1 & 4 \\
III & 1.0 & 1.0 & 0.2 & 6 \\
IV & 1.5 & 1.5 & 0.3 & 10 \\
V & 2.0 & 2.0 & 0.4 & 15 \\
\hline
\end{tabular}

*State Environmental Protection Administration (2002)

\section{Results}

The cause analysis of the black and odorous river bodies indicates that the river basin is mainly affected by agricultural non-point source pollution. Considering the segmented features of the pollution status, the author put forward a pollution control 
plan focusing on pollutant interception, source control, and ecological construction. The plan mainly covers five areas, namely, sewage treatment plant, sponge city, garbage treatment and sediment cleaning, rural water pollution control and wetland construction.

Table 3. Non-point pollution load in the river basin

\begin{tabular}{c|c|c|c|c|c|c|c}
\hline Land use & Area km & Percentage \% & TSS & COD & TN t/a & TP & NH3-N \\
\hline Farmland & 53.47 & 54.5 & 2491.7 & 498.3 & 74.8 & 7.5 & 24.9 \\
Rural construction land & 13.39 & 13.6 & 1559.9 & 468.0 & 31.2 & 3.1 & 12.5 \\
Urban factory land & 7.6 & 7.7 & 929.7 & 796.9 & 18.6 & 1.9 & 5.3 \\
Urban residential land & 11.36 & 11.6 & 1032.3 & 894.6 & 24.1 & 2.4 & 6.9 \\
Forest land & 3.72 & 3.8 & 26 & 13.0 & 1.3 & 0.1 & 0.3 \\
Grass land & 5.83 & 5.9 & 54.3 & 27.2 & 2.7 & 0.3 & 0.5 \\
Water body & 2.75 & 2.8 & & & & & \\
Total & 98.12 & 100 & 6093.9 & 2698 & 152.6 & 15.3 & 50.4 \\
\hline
\end{tabular}

*TSS: total suspended solids. COD: chemical oxygen demand. TN: total nitrogen. TP: total phosphorus. NH3-N: ammonia nitrogen

(1) The sediment and garbage were removed from 46.4-km-long river channels. In total, $8.4 \times 10^{4} \mathrm{~m}^{3}$ of sludge was cleaned away, which effectively reduces the sediment release and boosts the flood discharge ability. The sediments being removed were separated from water through a five-stage coagulative precipitation tank, dried in open air, and finally backfilled (Bohn, 2002). After dredging, COD and $\mathrm{NH}_{3}-\mathrm{N}$ index of the river cut nearly 50\%, after dredging, adding the volcanic debris (size $6 \sim 10 \mathrm{~mm}$ ) and pebbles on the bottom of the riverbed sediment improvement, on the microorganism immobilized bacterium agent, the bacteria agent by photosynthetic bacteria, spores, bacteria, to produce alkali bacteria, yeast and other 10 genera and more than 120 kinds of microorganism distribution and slow release cycle for $3 \sim 6$ months.

(2) The sponge city project was implemented in view of the following facts: the surface runoff coefficient (0.7) and surface runoff is obviously higher in the built-up area than other areas in the basin, the water quality is greatly affected by surface runoff, and the ecosystem is serious undermined. Specifically, a $0.8 \mathrm{~km}^{2}$ wetland park was built in the upstream of the DXK River and another $5.4 \mathrm{~km}^{2}$ one was constructed in the downstream of the JQ Ditch. The two parks were constructed to restore the natural water system and wetlands, which can retain, regulate and purify the surface runoff pollution, reduce the load of non-point pollution from the upstream, and ensure the ecological flow in the river basin. In addition, a pilot program of sponge city was implemented in the middle reaches of the WZ Ditch. The $4.7 \mathrm{~km}^{2}$ sponge city could cut down the surface runoff load by $50 \sim 75 \%$.

(3) The 82 ponds in the basin were expanded into a pond-wetland system. To maintain the water volume and purify the water in the basin, the following key wetlands were constructed: two reservoir wetlands, three pond wetlands, one estuary wetland and one artificially enhanced wetland (using the tail water from sewage treatment plant) (Ascelin et al., 2002; Zhu et al., 2019; Barinova, 2017). The area, pondage, and pollution reduction amount of each wetland are listed in Table 4. The locations of the wetlands are shown in Figure 2.

(4) The urban sewage was carried by lift pump stations to the sewage treatment plant for centralized treatment. The plant was newly constructed, with a capacity of 
$1 \times 10^{4} \mathrm{t} \cdot \mathrm{d}^{-1}$. Using the Anaerobic/Anoxic/Oxic (A/A/O) process, the sewage treated by the plant can reach the IA level in the Discharge Standard of Pollutants for Municipal Wastewater Treatment Plant (GB18918-2002). The pollutant interception pipe network was constructed as an auxiliary project of the plant. The quality of the treated sewage is illustrated in Figure 3.

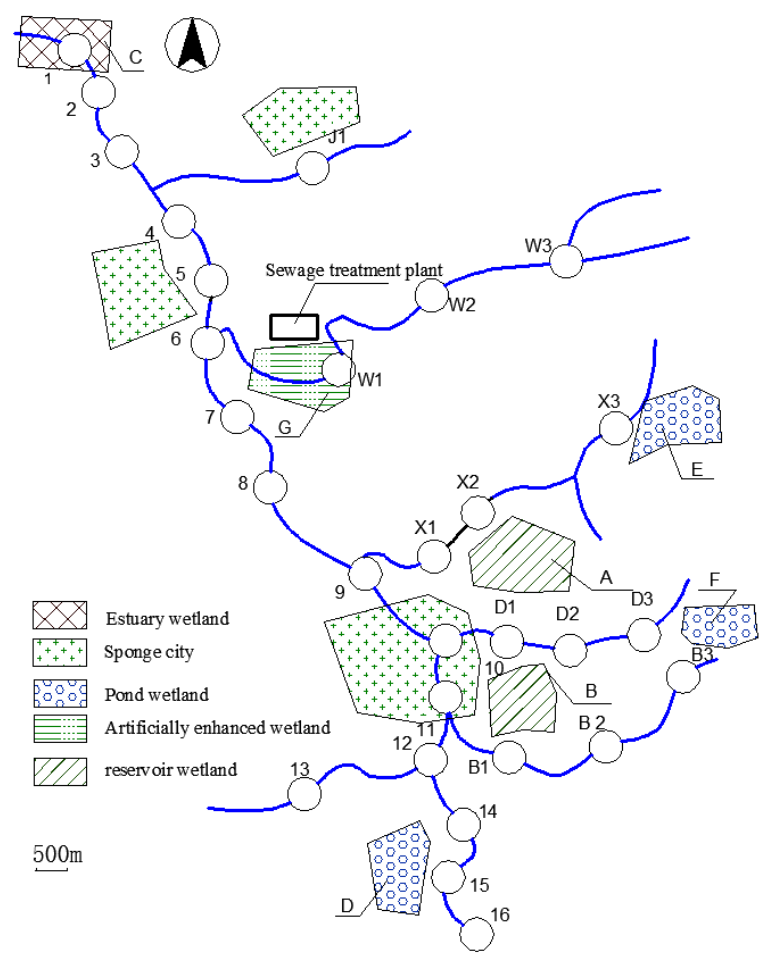

Figure 2. Distribution of different types of wetlands and sponge cities. (J: JQ Ditch, W: WZ Ditch, X: XBZ Ditch, D: DBZ Ditch, B: BZ Ditch)

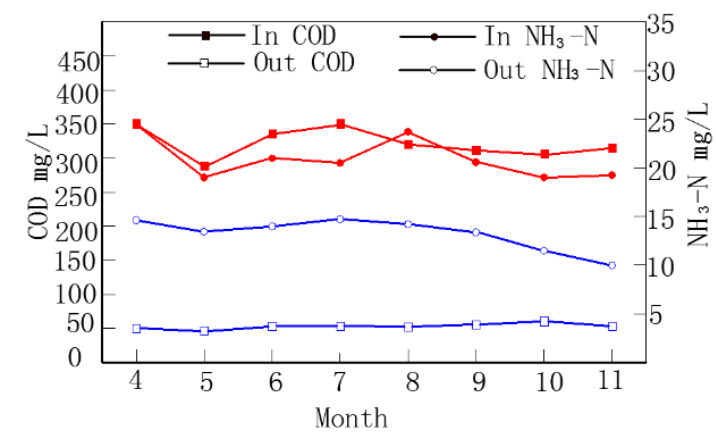

Figure 3. Comparison between inlet and outlet water of the A/A/O sewage treatment plant

(5) In light of the scattered discharge of rural sewage in the basin, the author developed a system to utilize and purify domestic sewage and rainwater. The system, encompassing rainwater and sewage collectors, sewage purifier, and ecological pools, can collect and purify domestic sewage and rainwater separately, and discharge them after they reached the relevant standard. In this way, the proposed system makes full use 
of water resources, and opens up a new way to replenish the groundwater. As shown in Figure 4, the sewage purifier consists of such four parts as sewage collector, primary purification tank, secondary purification tank and tertiary purification tank. The primary purification tank has three layers, which respectively filters coal cinder, medium-coarse sand and fine sand. The secondary purification tank mainly relies on a fiber filter layer consists of bio-fiber straws extracted from corn and wheat. This layer provides the function of biological purification. The tertiary purification tank works with an activated carbon filter layer. After entering the sewage purifier, the sewage passes through the three purification tanks in turn, and undergoes thorough purification.

Table 4. Statistics of multi-level pond-wetland system in the basin

\begin{tabular}{|c|c|c|c|c|c|c|c|c|c|}
\hline No. & Type of project & Longitude & Latitude & River & $\underset{\left(10^{4} \mathrm{~m}^{2}\right)}{\text { Area }}$ & $\begin{array}{c}\text { Pondage } \\
\left(10^{4} \mathrm{~m}^{3}\right)\end{array}$ & $\begin{array}{c}\text { COD } \\
\text { reduction } \\
(t / a)\end{array}$ & $\begin{array}{c}\mathrm{NH}_{3}-\mathrm{N} \\
\text { reduction } \\
(\mathrm{t} / \mathrm{a})\end{array}$ & Function \\
\hline 1 & Reservoir wetland A & 125.443561 & 43.892365 & XBZ Ditch & 4 & 6 & 9.8 & 2.4 & $\begin{array}{c}\text { Water storage and } \\
\text { purification }\end{array}$ \\
\hline 2 & Reservoir wetland B & 125.444718 & 43.873799 & DBZ Ditch & 4.9 & 8.1 & 11.2 & 3.1 & $\begin{array}{c}\text { Water storage and } \\
\text { purification }\end{array}$ \\
\hline 3 & Estuary wetland C & 125.366975 & 43.957737 & $\begin{array}{l}\text { DXK River - } \\
\text { Yitong River }\end{array}$ & 16.1 & 6.1 & 64 & 12 & Water purification \\
\hline 4 & Pond wetland D & 125.426149 & 43.861221 & DXK River & 6.5 & 9.8 & 43.1 & 6.9 & $\begin{array}{c}\text { Water storage and } \\
\text { purification }\end{array}$ \\
\hline 5 & Pond wetland $\mathrm{E}$ & 125.460136 & 43.885143 & XBZ Ditch & 5.5 & 8.3 & 38.4 & 5.9 & $\begin{array}{c}\text { Water storage and } \\
\text { purification }\end{array}$ \\
\hline 6 & Pond wetland $\mathrm{F}$ & 125.4700 & 43.871532 & DBZ Ditch & 8.7 & 13.1 & 57.6 & 9.2 & $\begin{array}{c}\text { Water storage and } \\
\text { purification }\end{array}$ \\
\hline 7 & $\begin{array}{c}\text { Artificially enhanced } \\
\text { wetland } G\end{array}$ & 125.410269 & 43.912186 & WZ Ditch & 7.8 & 5 & 18.2 & 2.3 & $\begin{array}{l}\text { Purification of tail } \\
\text { water from sewage } \\
\text { treatment plant }\end{array}$ \\
\hline
\end{tabular}

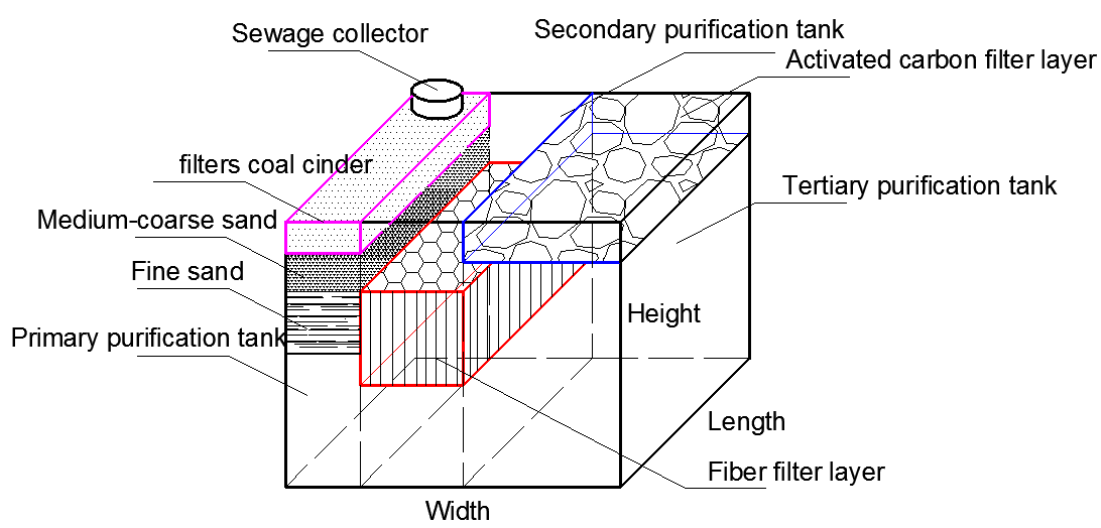

Figure 4. Sewage purifier

\section{Discussion}

The treatment of black and odorous waterbody should be adapted to local conditions and different treatment schemes should be adopted in different areas. The lower reaches of Fuchuangxi River in HaiNan province of China are tidal river sections with high salinity. Therefore, sewage interception, wastewater treatment, aeration and mangroves ecosystem were used to remediate the black and odorous waterbody of Fuchuangxi River (Chi et al., 2019). Yitng river of JiLin province, black and odorous waterbody is 
caused by farming and agriculture, so the construction of biogas greenhouse ecological system, heat storage and utilization of the manure, straw compost renewal, on the one hand, can make use of biogas technology in biochemical treatment, on the other hand can purify livestock farming aquaculture wastewater, reduce its pollution material such as COD, nitrogen, phosphorus content, reach discharge standards to reduce the surface water pollution (Zhao et al., 2019). Considering the segmented features of the pollution status, the author put forward a pollution control plan focusing on pollutant interception, source control, and ecological construction. The pollution control plan mainly covers five areas, namely, sewage treatment plant, sponge city, garbage treatment and sediment cleaning, rural water pollution control and wetland construction.

The pollution control plan was fully implemented by October 2017. From May to November, 2018, the author collected water samples from the DXK River at sampling points 5, 11 and 14, and analyzed the DO, ORP, $\mathrm{NH}_{3}-\mathrm{N}$ and transparency of the samples. The results in Figure 5 show that, through the seven months, the DO values at all three points were greater than $2 \mathrm{mg} / \mathrm{L}$, the $\mathrm{NH}_{3}-\mathrm{N}$ values were all smaller than $8 \mathrm{mg} / \mathrm{L}$ and the water transparencies were all above $25 \mathrm{~cm}$, indicating that the river is no longer black or odorous. The implementation of the entire plan costs USD $3.47 \times 10^{8}$. The investment is break down in Table 5.

Table 5. Main workloads and investment breakdown of the pollution control plan

\begin{tabular}{|c|c|c|c|c|}
\hline No. & Name of project & Project contents & Workload & $\begin{array}{c}\text { Investment } \\
\text { (USD thousand) }\end{array}$ \\
\hline 1 & $\begin{array}{l}\text { Drainage system and } \\
\text { sewage treatment plant }\end{array}$ & $\begin{array}{c}\text { Main sewage pipes ng the rivers } \\
\text { Rainwater and sewage interception wells } \\
\text { Sewage treatment plant }\end{array}$ & $\begin{array}{l}\text { Pollutant interception pipes (49 km) } \\
\text { Interception wells (39) } \\
110^{4} \mathrm{~m}^{3} / \mathrm{d}\end{array}$ & $\begin{array}{l}45714 \\
55714 \\
29997\end{array}$ \\
\hline 2 & Sponge city & $\begin{array}{c}\text { Green rainwater foundation } \\
\text { Green road construction } \\
\text { Green communities and squares }\end{array}$ & $\begin{array}{c}0.8 \mathrm{~km}^{2} \\
5.9 \mathrm{~km} \times 45 \mathrm{~m} \\
4 \mathrm{~km}^{2}\end{array}$ & $\begin{array}{l}14286 \\
8286 \\
28571\end{array}$ \\
\hline 3 & Sediment cleaning & $\begin{array}{c}\text { Mechanical dredging } \\
\text { Dehydration and capacity reduction } \\
\text { Transport and disposal }\end{array}$ & $\begin{array}{l}30 \text { places } \\
84514 \mathrm{~m}^{3} \\
94514 \mathrm{~m}^{3}\end{array}$ & $\begin{array}{r}214 \\
1207 \\
714\end{array}$ \\
\hline 4 & $\begin{array}{l}\text { Rural water pollution } \\
\text { control }\end{array}$ & $\begin{array}{c}\text { Village demolition } \\
\text { Domestic sewage treatment } \\
\text { Fecal composting } \\
\text { Others }\end{array}$ & $\begin{array}{c}3500 \mathrm{~J}^{3} \\
20000 \mathrm{~J}^{3} \\
1 \text { station } \\
\quad /\end{array}$ & $\begin{array}{c}5000 \\
2857 \\
2143 \\
571\end{array}$ \\
\hline 5 & Wetland construction & $\begin{array}{c}\text { Estuary wetland } \\
\text { Artificially enhanced wetland } \\
\text { Reservoir wetlands } \\
\text { Pond wetlands }\end{array}$ & $\begin{array}{l}100,000 \mathrm{~m}^{2} \\
78,000 \mathrm{~m}^{2} \\
106,000 \mathrm{~m}^{2} \\
65,000 \mathrm{~m}^{2}\end{array}$ & $\begin{array}{c}571 \\
1114 \\
1514 \\
650\end{array}$ \\
\hline 6 & Water ecological project & $\begin{array}{c}\text { Rubber dams } \\
\text { Ecological revetment } \\
\text { River landscape } \\
\text { Parks } \\
\text { Wetland spaces } \\
\text { Riverfront landscape belt } \\
\text { Leisure nodes }\end{array}$ & $\begin{array}{c}4 \\
\text { Soil and earthworks } 52,600 \mathrm{~m}^{3} \\
990,000 \mathrm{~m}^{2} \\
1160,000 \mathrm{~m}^{2} \\
170,000 \mathrm{~m}^{2} \\
810,000 \mathrm{~m}^{2} \\
210,000 \mathrm{~m}^{2}\end{array}$ & $\begin{array}{c}929 \\
511 \\
28285 \\
82857 \\
7286 \\
40500 \\
13500\end{array}$ \\
\hline \multicolumn{4}{|c|}{ Total } & $3.74 \times 10^{8}$ \\
\hline
\end{tabular}




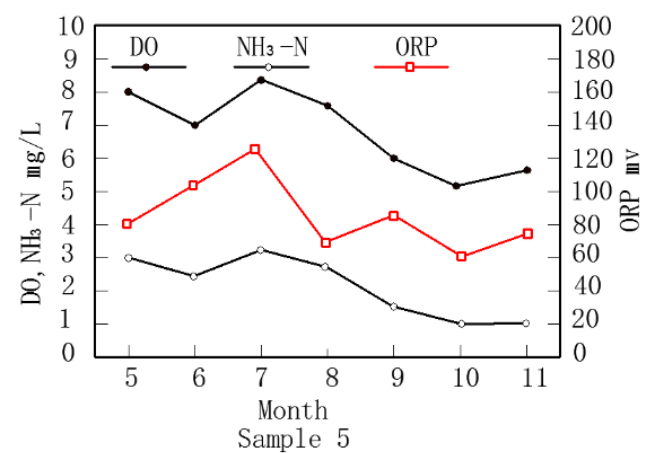

(a)

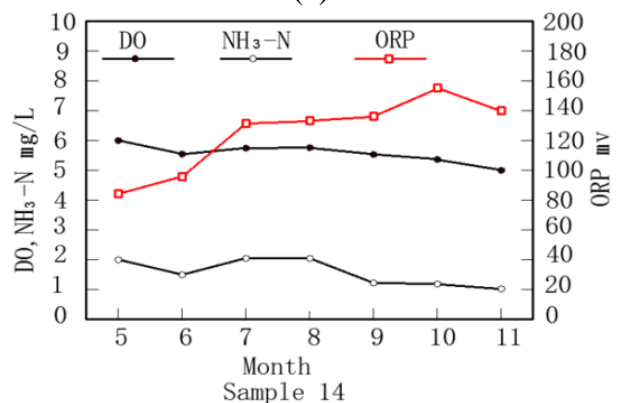

(c)

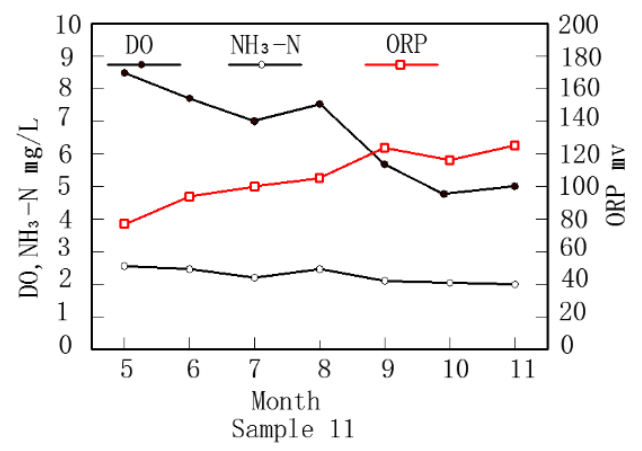

(b)

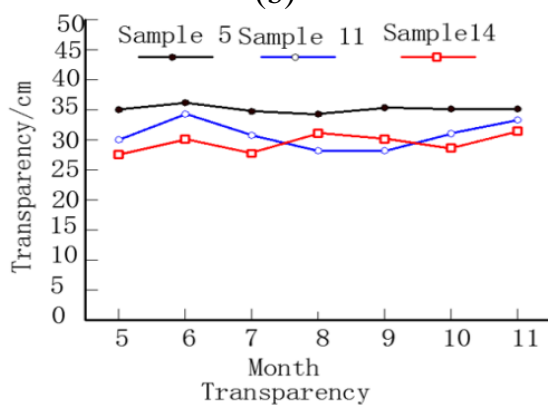

(d)

Figure 5. Analysis results on water sample quality

\section{Conclusions}

This paper monitors and analyzes the surface water and sediments in the DXK River basin, and discovers that the water bodies mainly suffer from aerobic pollution, with COD and NH3-N being the primary pollutants. Agricultural non-point source pollution accounts for $70 \%$ of the pollution load, and scattered discharge of rural sewage accounts for $5 \%$ of the pollution load, which is the main source of water pollution.

Considering the main causes of the pollution, the author put forward an integrated pollution control plan for the basin focusing on pollutant interception, source control, and ecological construction.

Removing the sediment and garbage from the river can reduce COD, NH3-N and other indicators in the river by nearly $50 \%$. The immobilized microbial agent was used to remove $\mathrm{NH}_{3}-\mathrm{N}$ and $\mathrm{COD}$ in black and odorous waterbody. The construction of wetland park, the ponds in the basin were expanded into a pond-wetland system, can significantly reduce $\mathrm{NH}_{3}-\mathrm{N}$ and COD.

After the treatment, the DO values at all sampling points were greater than $2 \mathrm{mg} / \mathrm{L}$, the $\mathrm{NH}_{3}-\mathrm{N}$ values were all smaller than $8 \mathrm{mg} / \mathrm{L}$ and the water transparencies were all above $25 \mathrm{~cm}$, indicating that the river is no longer black or odorous. The implementation of the entire plan costs USD $3.47 \times 10^{8}$. The research findings shed important new lights on pollution control in other rivers across China.

Also suggested that the basin water pollution comprehensive treatment to pollution load distribution in the process, on the one hand, it can realize basin within the scope of reasonable layout and the load sharing ratio of the control area, on the other hand, within the scope of the basin can be unequal distribution of technical and economic investment, implement the specific implementation of total amount control load index, the governance effect is better. 
Acknowledgment. This paper is made possible thanks to the generous supports from Science and Technology Department, Jilin Province (Grant No.: 20180101339JC and 20190303022SF), Education Department, Jilin Province (Grant No.: JJKH20180575KJ and JJKH20180600KJ), Laboratory of GeoExploration Instrumentation, Jilin University (Grant No.: ERCGR201704) and the National Natural Science Foundation of China (Grant No.: 51878316).

\section{REFERENCES}

[1] Ascelin, G., David, S., Matt, W., Atte, M., Sarah, A. B. (2008): Integrating conservation planning and landuse planning in urban landscapes. - Landscape and Urban Planning 91(4): 183-194.

[2] Barinova, S. S. (2017b): Empirical model of the functioning of aquatic ecosystems. International Journal of Oceanography and Aquaculture 1(3): 1-9.

[3] Behaddya, M. L., Hadjel, M. (2014): Spatial distribution and contamination assessment of heavy metals in surface soils of Hassi Messaoud, Algeria. - Environmental Earth ciences 71(3): 1473-1486.

[4] Bhuiyan, M. A., Parvez, L., Isiam, M. A., Dampare, S. B., Suzukia, S. (2010): Heavy metal pollution of coal mine-affected agricultural soils in the northern part of Bangladesh. - Journal of Hazardous Materials 173(1-3): 384-392.

[5] Bohn, B. A., Kershner, J. L. (2002): Establishing aquatic restoration priorities using a watershed approach. - Journal of Environmental Management 64(4): 355-363.

[6] Chi, J., Jiang, Y., Yuan, X. K. (2019): Remediation project of black and odorous waterbody of Fuchuangxi and Dapaigou with one river and one policy. - Chinese Journal of Environmental Engineering 13(2): 496-504.

[7] Corsino, S. F., Capodici, M., Morici, C. (2016): Simultaneous nitritation-denitritation for the treatment of high-strength nitrogen in hypersaline wastewater by aerobic granular sludge. - Water Res. 88: 329-336.

[8] Lazaro, T. (1979): Urban Hydrology. - Ann Arbor Science Publishers, Michigan.

[9] Li, S., Shi, W., Li, H. (2018): Antibiotics in water and sediments of rivers and coastal area of Zhuhai City, Pearl River estuary, south China. - Science of the Total Environment 636: 1009-1019.

[10] Moungar, H., Azzi, A., Sahli, Y., Haida, A. (2018): Monthly fresh water yield analysis of three solar desalination units a comparative study in the south Algeria climatic condition. - International Journal of Heat and Technology 36(4): 1330-1335.

[11] Podani, J. (1994): Multivariate Data Analysis in Ecology and Systematics. - SPB Publishing, The Hague.

[12] State Environmental Protection Administration (2002): Water and Wastewater Detection and Analysis Method. - China Environmental Science Publishing House, Beijing.

[13] Uddin, M. J., Halim, M. A., Mohiuddin, M. (2017): Copper oxide-water nanofluid flow within an annulus shaped cavity: a numerical study on natural convective heat transfer. Annales de Chimie - Science des Matériaux 41(3-4): 239-260.

[14] Wang, G. F., Li, X. N., Fang, Y., Huang, R. (2014): Analysis on the formation condition of the algae-induced odorous black water agglomerate. - Saudi Journal of Biological Sciences 21(6): 597-604.

[15] Wang, X., Wang, Y. G., Sun, C. H. (2016a): Formation mechanism and assessment method for urban black and odorous water body: a review. - Chinese Journal of Applied Ecology 27(4): 1331-1340.

[16] Wang, Y. Q., Bai, Y. R., Wang, J. Y. (2016b): Distribution of urban soil heavy metal and pollution evaluation in different functional zones of Yinchuan City. - Environmental Sciene 37(2): 710-716. 
[17] Xu, Z. X. (2005): Comprehensive water quality identification index for environmental quality assessment of surface water. - Journal of Tongji University: Natural Science 33(4): 482-488.

[18] Zhao, S. Y., Su, X., Zhao, S. (2016): A study on the water pollution of poultry and livestock breeding and the resource utilization of the wastewater in Sonln Village. Chemical Engineering Transactions 55: 469-474.

[19] Zhao, S. Y., Qin, Y. Q., Zheng, H. N., Chen, L. (2019): Construction of the biogas heat strorage greenhouse ecosystem under the context of water pollution resulting from livestock breeding. - Environmental Engineering and Management Journal 18(3): 757763.

[20] Zhou, S. L., Li, R. H., Wu, S. H. (2011): Study on Relations between the Economic Development and the Spatial and Temporal Variation of Heavy Metals in Agricultural Land. - China Land Press, Beijing.

[21] Zhu, W. T., Liu, Y. Y., Wang, S. T., Yu, M., Qian, W. (2019): Development of microbial community-based index of biotic integrity to evaluate the wetland ecosystem health in Suzhou, China. - Environmental Monitoring and Assessment 191(6): 1-11. 